\title{
Mechanical properties and energy dissipation of rock under acid corrosion and coupled static-dynamic loads
}

\author{
Liu Yong-sheng ${ }^{1}$, Li Jin ${ }^{1}$, Zou Jia-yu ${ }^{1}, W u$ Qin-lan ${ }^{1}$ Liu Wang ${ }^{2}$ \\ ${ }^{1}$ School of Civil Engineering and Architecture, East China Jiaotong \\ University, Nanchang jiangxi 330013, P.R.China \\ ${ }^{2}$ Nanchang Munici pal Public Investment Group Co., Ltd.Nanchang, \\ Nanchang jiangxi 330029, P.R.China
}

\section{Received August 23,2017}

The dynamic impact experiment were carried out to investigate the dynamic mechanical properties of different types of rocks under acidic environment and coupled static-dynamic loads. The experimental results showed that the mechanical properties of marble and red sandstone are affected by acid corrosion, impact pressure and coupled loading. Based on the principle of energy conservation and the experimental results, the energy dissipation law of the red sandstone under coupled static-dynamic loads was analyzed. The analysis results show that with the increasing of the impact pressure, the average strain rate increases, and the incident energy increases linearly, and the reflection energy and energy absorption show a slow growth trend; The transmission energy is almost unaffected by the impact pressure, and the fitting curve is approximate to a straight line. The results show that there is an obvious correlation between the dynamic strength of rock and the absorbed energy. The higher the impact pressure is, the greater the absorption energy is, the higher the strength of the rock under static and dynamic combination is.

Key words: rock mechanics; chemical corrosion; coupled static-dynamic loads; mechanical properties; energy dissipation

Исследовано влияние динамических и статических нагрузок на механические свойства различных типов пород в кислой среде. Экспериментальные результаты показали, что на механические свойства мрамора и красного песчаника влияют кислотная коррозия, ударное давление и статическая нагрузка. На основе принципа энергосбережения и результатов эксперимента проанализирован закон о рассеивании энергии красного песчаника при связанных статически-динамических нагрузках. Результаты анализа показывают, что при увеличении ударного давления средняя скорость деформации возрастает, энергия разрушения растет линейно, а энергия отражения и поглощение энергии проявляют медленный рост. Энергия передачи практически не зависит от ударного давления, а кривая фитинга приближается к прямой. Результаты показывают, что существует корреляция между динамической прочностью породы и поглощенной энергией. Чем выше ударное давление, тем больше энергия поглощения, тем выше прочность породы при статической и динамической комбинациях воздействия.

Механічні властивості і диссипация енергії гірської породи при кислотному впливі і пов'язаних статично-динамічних навантаженнях. Liu Yong-sheng, Li Jin, Zou Jia-yu, Wu Qin-lan, Liu Wang

Досліджено вплив динамічних і статичних навантажень на механічні властивості різних типів порід в кислому середовищі. Експериментальні результати показали, що на механічні 
властивості мармуру і червоного пісковика впливають кислотна корозія, ударний тиск i статичне навантаження. На основі принципу енергозбереження та результатів експерименту проаналізовано закон про розсіювання енергії червоного пісковика при пов'язаних статичнодинамічних навантаженнях. Результати аналізу показують, що при збільшенні ударного тиску середня швидкість деформації зростає, енергія руйнування зростає лінійно, а енергія відображення і поглинання енергії виявляють повільне зростання. Енергія передачі практично не залежить від ударного тиску, а крива фітинга наближаеться до прямої. Результати показують, що існуе очевидна кореляція між динамічної міцністю породи $\mathrm{i}$ енергією поглинання. Чим вище ударний тиск, тим більше енергія поглинання, тим вище міцність породи при статичної та динамічної комбінаціях впливу.

\section{Introduction}

The deep rock is a kind of heterogeneous brittle media, the internal micro cracks are continuously developed and expanded under the influence of the deep complex environment and the high ground stress[1]. The rock mass with micro damage is subjected to dynamic loads due to excavation disturbance when the rock excavation under the condition of high stress. Therefore, the rock mass is subjected to complex dynamic and static loads, which results in the unstable development of rock crack and the failure. Guo L J et al. [2] studied the dynamic mechanical properties of granite under different impact pressures using the SHPB. The stress-strain relationship and failure process of rock under impact loading are discussed. It is found that the rock deformation process can be divided into four stages: initial compaction, stable deformation, nonlinear elasticity and failure. J.C.Li et al.[3] has performed dynamic mechanical tests of fractured rocks using the SHPB, and the propagation law of stress wave in fractured rock mass was discussed. The results showed that fracture width and water content have great influence on stress-strain relationship of fractured rock mass under dynamic action. According to the needs of deep rock mechanics, Li Xi-bing et al. [4-6] developed a static and dynamic loading test system for rock with medium and high strain rate, and the system is tested with different axial pressure, confining pressure and dynamic load. The results show that the dynamic strength of rock can be improved obviously by axial compression. The dynamic strength of rock increases with the increase of dynamic load, which shows the strain rate dependence under the combined action of static and dynamic loads. Zhao Fujun et al. [7] carried out the study of acoustic emission of rock under combined static and dynamic loading, the relationship between the acoustic emission energy, the load form and the crushing volume is analyzed. Yin tubing et al.
[8] carried out the energy dissipation analysis of the rock under thermo-mechanical coupling. The results show that, at a given dynamic load, rock samples rock samples at temperatures of $20^{\circ} \mathrm{C}, 200^{\circ} \mathrm{C}$ and $300^{\circ} \mathrm{C}$ and axial pressure of 20 $\mathrm{MPa}$ have the maximal energy-absorb capability, but at temperature of $100^{\circ} \mathrm{C}$ rock samples under axial pressure of $0 \mathrm{MPa}$ have the maximal energy-absorb capability.

With the development of deep underground engineering, many scholars[9-12] have carried out the research on the mechanical characteristics and energy dissipation of rock, and obtained a lot of meaningful research results. the influence of the deep underground complex environment on the rock properties can't be ignored. The acidity of deep groundwater plays an important role in the performance, failure mode, energy dissipation and so on. In this paper, we take into account the actual situation of deep underground engineering, acidified rock with acidic solution of $\mathrm{pH}=4$. The impact test using static and dynamic system were conducted, and the energy dissipation law of the specimen are analyzed.

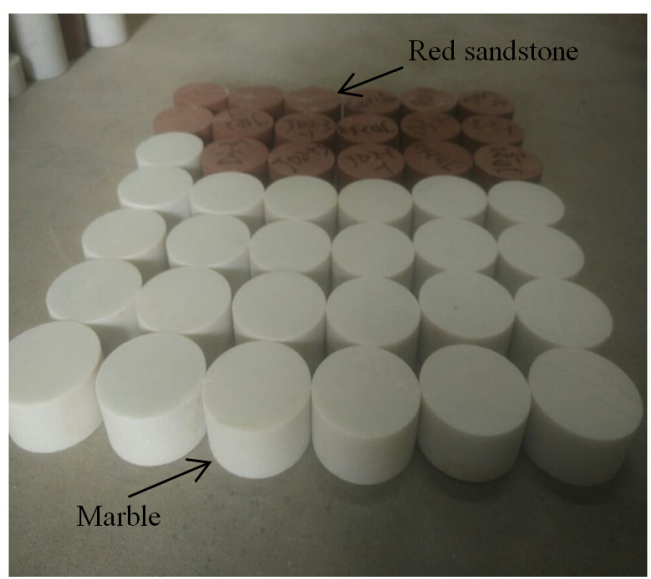

Fig. 1. Rock specimens 
Table 1 The classification of loading mode

\begin{tabular}{|c|c|c|c|c|c|c|c|}
\hline Test section & \multicolumn{4}{|c|}{ Impact pressure (MPa) } & $\begin{array}{c}\text { Axial static } \\
\text { pressure } \\
(\mathrm{MPa})\end{array}$ & $\begin{array}{c}\text { Confining } \\
\text { pressure } \\
(\mathrm{MPa})\end{array}$ \\
\hline Pure dynamic & 0.45 & 0.50 & 0.55 & - & - & - & - \\
\hline One-dimensional & 0.45 & 0.50 & 0.55 & 0.60 & 0.65 & 8 & - \\
\hline Three-dimensional & 0.55 & 0.65 & 0.75 & 0.85 & - & 8 & 2 \\
\hline
\end{tabular}
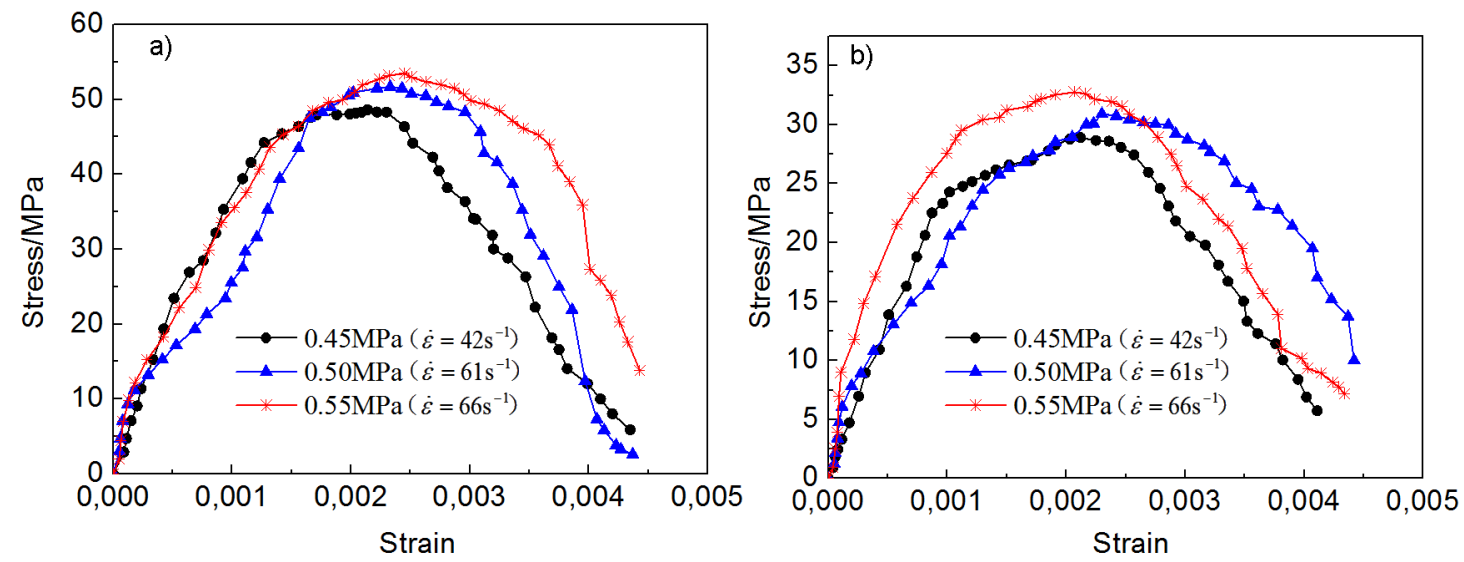

Fig. 2. The stress-strain curve under the action of pure dynamic loading. (a) red sandstone, (b) marble.
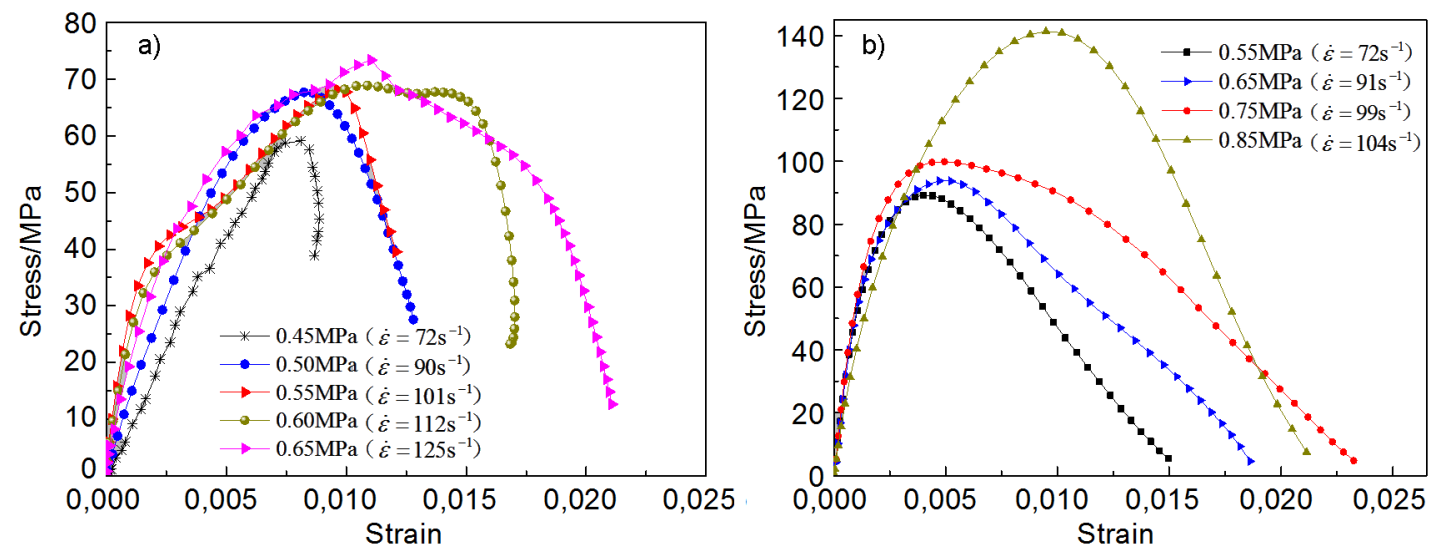

Fig. 3. The stress-strain curves of specimens under different conditions (a) one-dimensional loading, (b) three-dimensional loading.

\section{Experiment}

Red sandstone and marble are selected as the object of study. red sandstone is a sedimentary rock, and its compositions are quartz, calcite and so on. Marble belongs to metamorphic rock, mainly composed of calcite and dolomite. The sample of rock were taken in the same rock stratum, and the specimens are cylinders with a diameter of $50 \mathrm{~mm}$ and a height of $25 \mathrm{~mm}$, shown as Figure 1.

In order to simulate the acidic environment of deep underground, the acid solution of $\mathrm{pH}=4$ were prepared by the method of diluting hy- drochloric acid, and then the specimen was immersed in the acid solution curing. The acidity of the solution was measured every 12 hours, and the $\mathrm{pH}$ value of acid solution was kept constant. The immersion time of the sample is 30 days.

The impact dynamic experiments are carried out by SHPB device and coupled static-dynamic loads device. The impact loads are pure impact loads, one-dimensional and three-dimensional coupled static-dynamic loads, the detailing loading schemes are shown as Table 1. 
Liu Yong-sheng et al. / Mechanical properties and energy dissipation ...

Table 2 The compression strength of specimens

\begin{tabular}{|c|c|c|c|c|c|c|c|c|c|c|c|c|c|}
\hline \multirow{2}{*}{$\begin{array}{l}\text { strength } \\
\text { (MPa) }\end{array}$} & \multirow{2}{*}{ Static } & \multicolumn{3}{|c|}{$\begin{array}{l}\text { Pure dynamic } \\
\text { Impact(MPa) }\end{array}$} & \multicolumn{5}{|c|}{$\begin{array}{l}\text { One-dimensional } \\
\text { Impact }(\mathrm{MPa})\end{array}$} & \multicolumn{4}{|c|}{$\begin{array}{l}\text { Three-dimensional } \\
\text { Impact }(\mathrm{MPa})\end{array}$} \\
\hline & & 0.45 & 0.50 & 0.55 & 0.45 & 0.50 & 0.55 & 0.60 & 0.65 & 0.55 & 0.65 & 0.75 & 0.85 \\
\hline Marble & 19.1 & 28.9 & 30.9 & 32.8 & - & - & - & - & - & - & - & - & - \\
\hline $\begin{array}{l}\text { Red sand- } \\
\text { stone }\end{array}$ & 31.0 & 48.6 & 51.7 & 53.5 & 59.1 & 67.9 & 68.5 & 69.0 & 73.4 & 89.2 & 93.8 & 99.9 & 141.3 \\
\hline
\end{tabular}
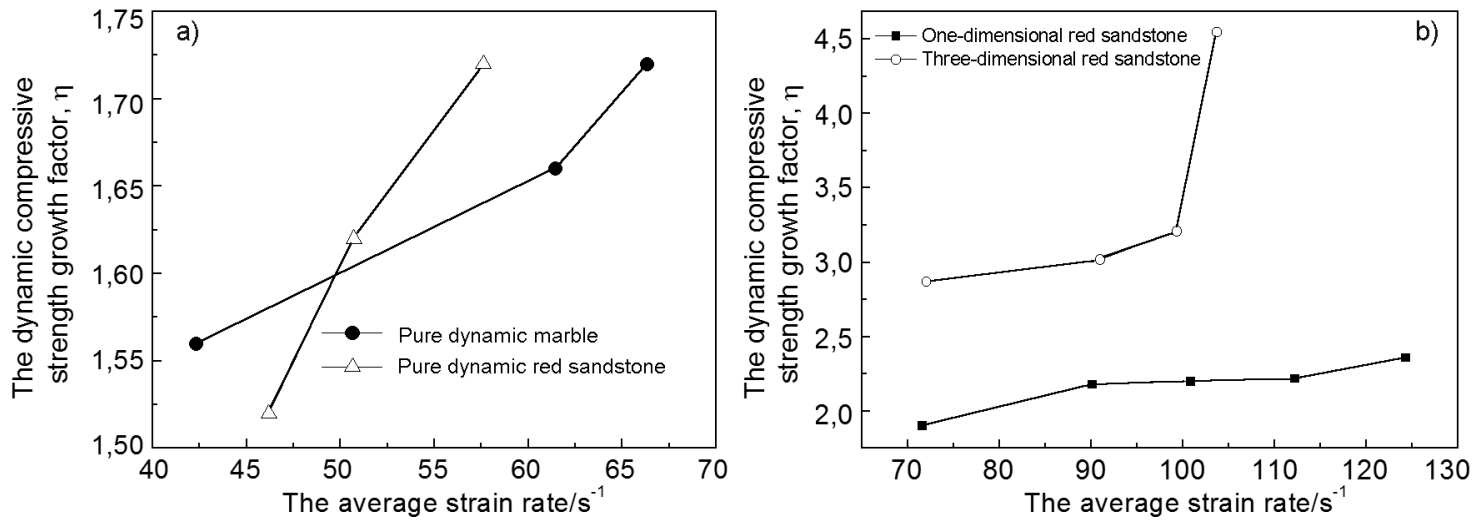

Fig. 4. Growth factor of dynamic strength, (a) pure dynamic, (b) coupled static-dynamic.

\section{Results and analysis}

The stress-strain curves of red sandstone and marble of the pure dynamic experiment is shown as Fig. 2, where $\dot{\varepsilon}$ is the average strain rate under different impact pressures.

From Fig. 4 we can found that the dynamic compression strength of red sandstone and marble increases with the impact pressure (average strain rate) increasing under pure dynamic loading. And the dynamic strength of the red sandstone is much larger than those of marble at close stain rate. The internal structure of red sandstone is more compact, acid corrosion has little effect on it, so after acid corrosion the dynamic mechanical properties of red sandstone reduce less. Due to the limitation of the experimental condition, the experiment of coupled static-dynamic loads carried out only for red sandstone, and the stress-strain curves of coupled static-dynamic loads are shown as Figure 3.

It can be found from Figure5. that the dynamic strength of red sandstone increases with the impact pressure increasing too under the one-dimensional and three-dimensional static-dynamic combined loading. The mechanical response of the acid red sandstone under one-dimensional loads and three-dimensional loads is similar, and all of process contain three main stages: the first stage is the elastic stage, the specimen is subjected to the instantaneous impact of the external load. At this point, the stress-strain curve of the rock shows a trend of upward growth. The cracks occur in specimen internal structure with the increasing of external impact time. Then specimen gradually enters the second stage, named the elastic-plastic stage. In this stage, the specimen began to damage by compression, but the stress is still rising till to the peak stress. The third stage is named plastic stage. At this stage the specimen loses its bearing capacity completely and the rock basically destroys. The stress-strain curve performs a rapid decrease from the peak stress point.

According to the stress-strain curves, the strength of the all specimens can be calculated shown in Table 2. In order to study the strength changing of the rock, the growth factor of strength is introduced in this paper, in which $\eta$ is the ratio of rock dynamic strength to uni-axial compression strength $\eta=\sigma_{d} / \sigma_{s}$. The growth factor $\eta$ of the specimens are shown in Figure 6. The growth factor $\eta$ of all specimens increased with the average strain rate increasing, and the effect of red sandstone is more obvious than marble under pure dynamic loads seen from Figure 4 (a). The growth factor $\eta$ of three-dimensional loads increase more obvious than one-dimensional loads with the strain rate rising form Figure 4 (b). Rock is a heterogeneous material, there are many original mi- 
Table 3. Compression strength of rock samples

\begin{tabular}{|c|c|c|c|c|c|}
\hline \multirow{2}{*}{\multicolumn{2}{|c|}{ Rock specimen }} & \multicolumn{2}{c|}{ Red sandstone } & \multicolumn{2}{c|}{ Marble } \\
\cline { 3 - 6 } & Normal curing & $\mathrm{pH}=4$ & Normal curing & $\mathrm{pH}=4$ \\
\hline \multirow{3}{*}{$\begin{array}{c}\text { The uniaxial } \\
\text { compressive } \\
\text { strength }(\mathrm{MPa})\end{array}$} & First group & 52.92 & 33.90 & 43.51 & 16.53 \\
\cline { 2 - 6 } & Second group & 60.64 & 28.67 & 36.25 & 19.85 \\
\cline { 2 - 6 } & Third group & 42.91 & 30.67 & 39.14 & 20.78 \\
\cline { 2 - 6 } & Average value & 52.16 & 31.08 & 39.63 & 19.05 \\
\hline
\end{tabular}
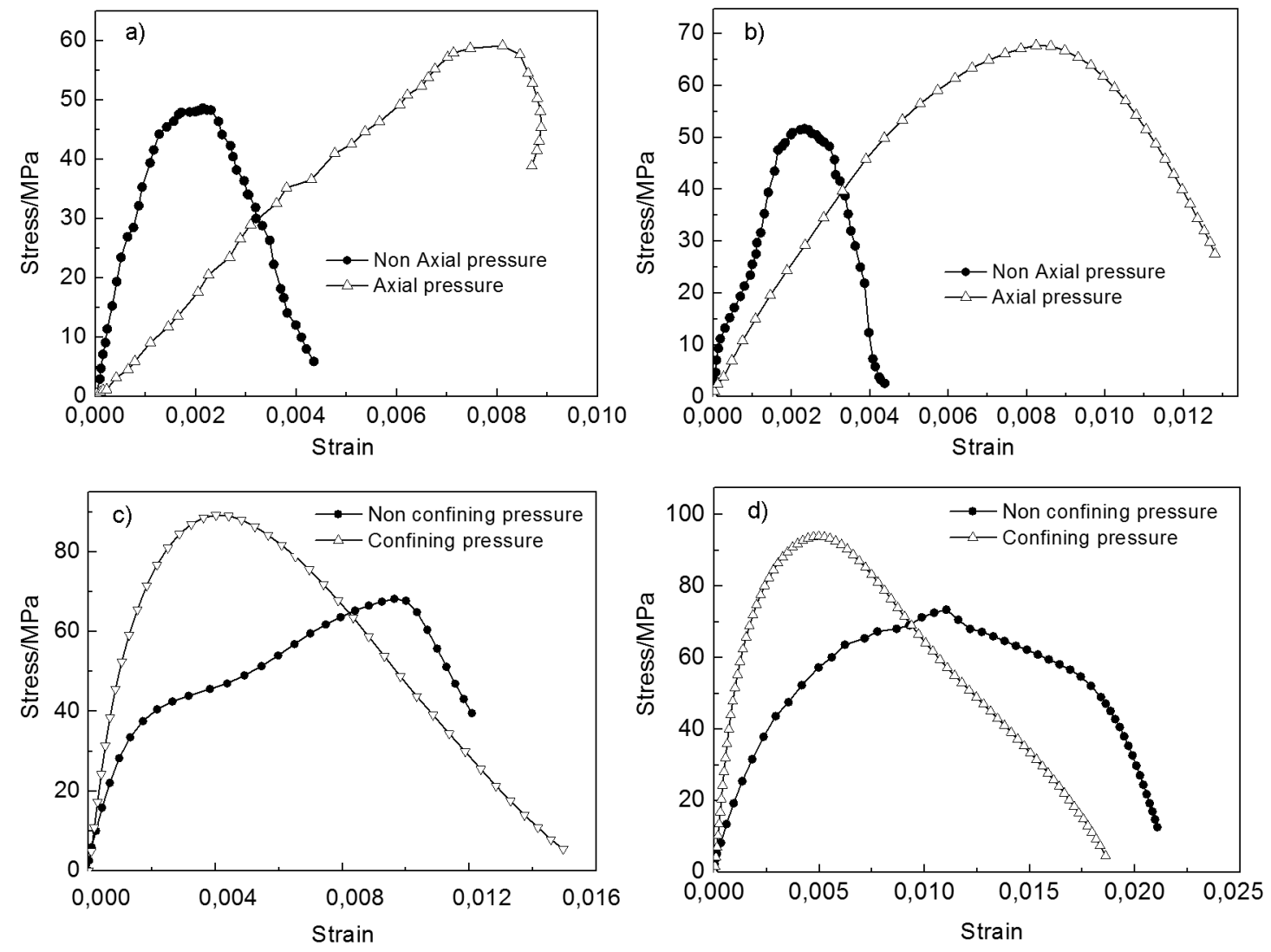

Fig. 5. Effect of axial pressure and confining pressure, (a) $\mathrm{P}=0.45 \mathrm{MPa}$, (b) $\mathrm{P}=0.50 \mathrm{MPa}$, (c) $\mathrm{P}=0.55 \mathrm{MPa}$, (d) $\mathrm{P}=0.65 \mathrm{MPa}$.

cro-crack inside the rock. At lower strain rate, the internal cracks of the rock have sufficient time to expand, so the specimen is easy to destroy, and the growth factor is not significantly. In high strain rate, the micro-cracks internal the rock is too late to expand, the bearing capacity improving. In contrast to one-dimensional loads and three-dimensional loads, the rock is subjected to three axis stress and has a great constraint effect under three-dimensional loads. The rock is not easy to crack under the dynamic impact load due to the great binding force, so the bearing capacity of the rock under three-dimensional loads improved more significantly.
In order to study the effect of acid environment on the mechanical properties of rock, the uniaxial compression experiment of the rock samples under acid and normal curing are carried out, and the results are shown in Table 3 . The results showed that the uniaxial compression strength of rock samples decreased in different degrees after $30 \mathrm{~d}$ immersion in $\mathrm{pH}=4$ acid solution. After immersed in acid solution, the average value of compression strength of red sandstone is $31.08 \mathrm{MPa}$, and it is $41.25 \%$ lower than that of normal curing. The average value of compression strength of marble is $19.05 \mathrm{MPa}$, which is $51.9 \%$ lower than be- 
fore. Form the test results, we know chemical corrosion has a great effect on the mechanical properties of the rock, especially to marble. So if there is a clear acidic environment in the underground project, we should do a good job on the performance of rock testing, and for security measures in advance.

Figure 5. (a), (b) are the stress-strain curves of the red sandstone under axial pressure and without axial pressure at the impact pressure of $0.45 \mathrm{MPa}$ and $0.5 \mathrm{MPa}$. And the stress-strain curves of the red sandstone under confining pressure and without confining pressure at the impact pressure of $0.55 \mathrm{MPa}$ and $0.65 \mathrm{MPa}$ shown as Figure 5. (c) (d). From the Figure 5 we see the axial and confining pressure have significant influence on the dynamic compression strength of red sandstone. When the impact pressure is $0.45 \mathrm{MPa}$ and $0.50 \mathrm{MPa}$, the peak stress of red sandstone under axial static load is $23.59 \%$ and $31.08 \%$ higher than that under non axial static load respectively. Thus, the axial static load greatly enhanced the peak stress of acid red sandstone. And it can be found that the peak strain of red sandstone under axial static loading is significantly higher than that under non axial static loading.

In the case of confining compression, the peak stress of the red sandstone under confining pressure is $30.79 \%$ and $27.87 \%$ higher than that of under non confining pressure when the impact pressure is $0.55 \mathrm{MPa}$ and $0.65 \mathrm{MPa}$ respectively. The confining pressure greatly enhanced the peak stress of acid red sandstone too. In deep underground environment, the dynamic compression strength of deep rock can be greatly improved because of the mutual compression of rock movement (confining pressure) caused by crustal movement.

\section{Discussion}

Based on the stress wave theory, the incident energy $W_{I}(t)$, the reflected energy $W_{R}(t)$ and transmitted energy $W_{T}(t)$ of split Hopkinson pressure bar (SHPB) can also be obtained as follows:

$$
\begin{aligned}
& W_{I}(t)=\frac{A_{e} C_{e}}{E_{e}} \int_{0}^{t} \sigma_{I}^{2}(t) d t \\
& W_{R}(t)=\frac{A_{e} C_{e}}{E_{e}} \int_{0}^{t} \sigma_{R}^{2}(t) d t \\
& W_{T}(t)=\frac{A_{e} C_{e}}{E_{e}} \int_{0}^{t} \sigma_{T}^{2}(t) d t
\end{aligned}
$$

where $A_{e}$ is the cross-sectional area of elastic rod; $C_{e}$ is the elastic rod wave velocity; $E_{e}$ is the elastic modulus of specimen; $\sigma_{I}(t), \sigma_{R}(t)$ and $\sigma_{T}(t)$ are the incident, reflection and transmission stresses.

The energy of the specimen is $W_{\mathrm{o}}=\int_{0}^{\varepsilon} \sigma(t) d \varepsilon(t)$ under the Uniaxial static load. For coupled static-dynamic loading, the axial pressure is added in SHPB system in advance. The absorbed energy $W_{\mathrm{S}}$ of the rock specimen under coupled static-dynamic loading can be calculated as formula (4):

$$
W_{S}=W_{I}+W_{O}-\left(W_{R}+W_{T}\right)
$$

Absorbed energy $W_{S}$ is mainly composed of three parts, of which the most important part is the fracture damage energy $W_{F D}$, its function is to formation fracture surface and crack, propagating and extending. The second part is the kinetic energy $W_{K}$ of rock fragments. The third part is other forms energy, such as heat energy and radiant energy etc.. When the loading rate is not very large, the heat energy and radiation energy can be neglected. The research results indicated that the kinetic energy $W_{K}$ of rock fragments is only about $5 \%$ of the absorbed energy $W_{\mathrm{S}}$, while the fracture damage energy $W_{F D}$ can reach to nearly $95 \%$ of the whole absorbed energy [13]. In this experiment, the specimens were corroded by acid solution, which led to the strength of the specimens lower, and there are few flying pieces after the specimens were damaged. So in the energy analysis, we used the absorption energy $W_{\mathrm{S}}$ to replace the fracture damage energy $W_{F D}$ in this paper.

According to the formula (1) (4), the energy of red sandstone under static-dynamic loading were calculated shown as Fig. 6 , where $A_{e}$ $=1.9625 \times 10^{-3} \mathrm{~m}^{2}, C_{e}=5797 \mathrm{~m} \cdot \mathrm{s}^{-1}, E_{e}=250 \mathrm{GPa}$.

It can be seen from Figure 6 that the incident energy $W_{I}$ of the acidified red sandstone increases with the average strain rate increasing, and them have a good linear relationship under onedimensional and three-dimensional static and dynamic combination. The reflected energy $W_{R}$ and the absorbed energy $W_{S}$ show a slow increasing trend with the average strain rate increasing, and the growth trend is similar. The transmitted energy is hardly affected by the average strain rate, and it is stable between $15 \sim 23 \mathrm{~J}$.

Absorption energy is an important factor to control the strength and failure mode of the materials. The relation curves between the dynamic compression strength and the absorbed 

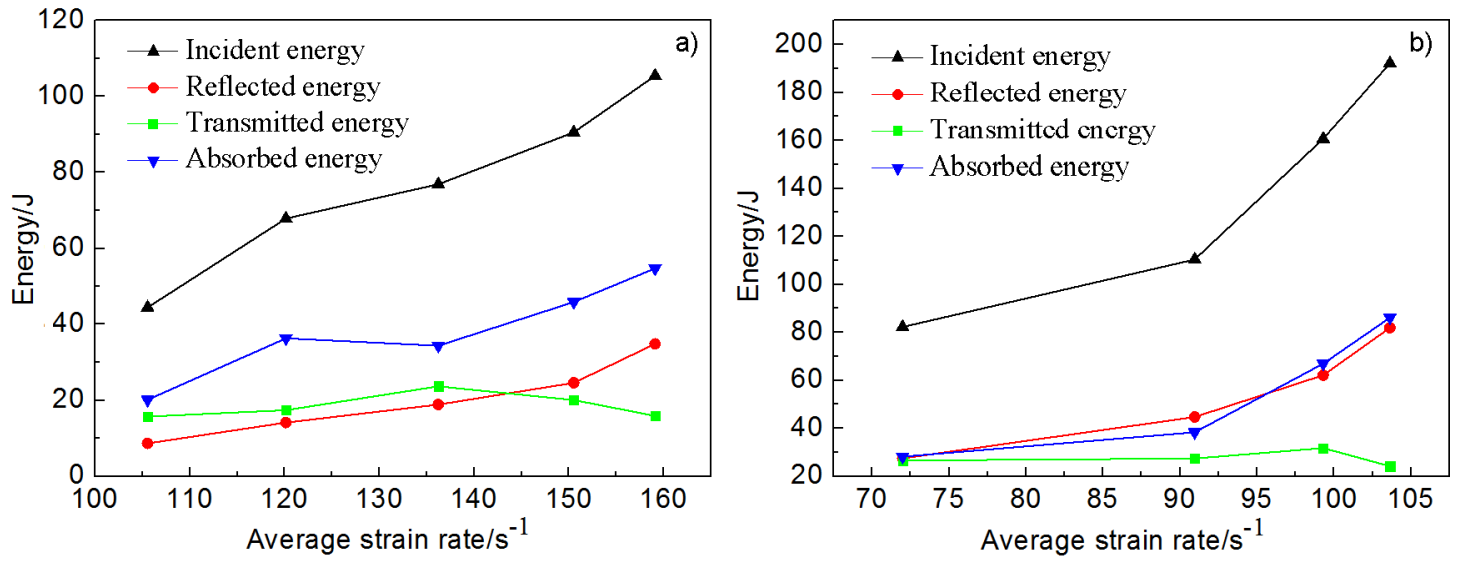

Fig. 6. The relationship between average strain rate and energy of acid red sandstone under the static and dynamic combination. (a) One-dimensional static and dynamic combination, (b)Three-dimensional static and dynamic combination.

energy of the experiment were given as shown in Figure 7. From Figure 8 we can see that the dynamic compression strength of the acidified red sandstone increases with the absorbed energy increasing whether in one-dimensional or threedimensional state, and The strength increase linearly almost with the absorption energy increasing under one-dimensional loading. In the case of three-dimensional loading, when the absorption energy is lower than 70J the dynamic strength increase linearly, while the absorption energy is higher than 70J, the dynamic strength increases sharply. As we know the absorbed energy increases, and the energy transfer lags, the original crack failed to develop and expand in time, causing to deformation and failure delaying, so the dynamic strength improves. This effect will be more obvious under three-dimensional loading. Under the condition of three-dimensional loading, micro cracks are difficult to expand because of confining pressure.

\section{Conclusions}

In this paper, the dynamic experiment of rock under acid corrosion and coupled staticdynamic loads are carried out, and the energy dissipation law of the rock is analyzed. The results show that:

The dynamic compression strength of red sandstone and marble increases with the increasing of impact pressure (average strain rate) under pure dynamic and one-dimensional and three-dimensional dynamic loads. The growth factor $\eta$ increase with the average strain rate rising, and the biggest $\eta$ reach to 4.5 for threedimensional coupled static-dynamic loads and 2.4 for one-dimensional. And axial pressure

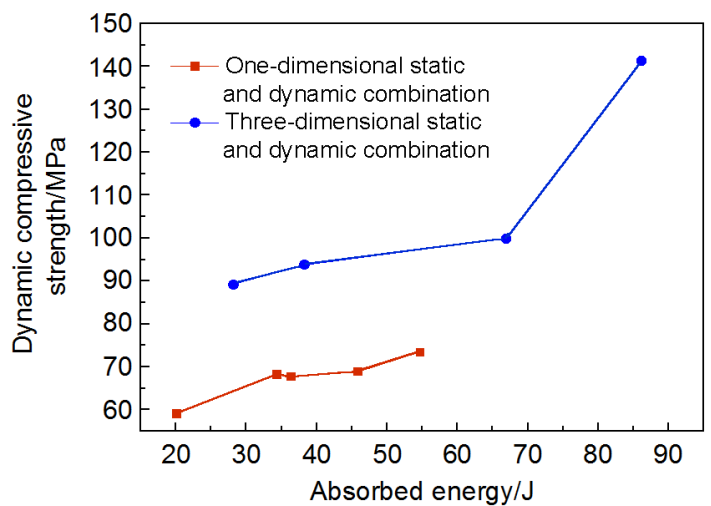

Fig. 7. The relationship between absorbed energy and dynamic compressive strength under the dynamic and static combination

and confining pressure have great influence on the strength of rock.

Acid corrosion has a significant effect on the performance of the rock. The strength of marble lose 51.9\% after 30 days acid immersing, and red sandstone losing $41.25 \%$. So the underground project under chemical corrosion should pay special attention to safety.

The incident energy, the reflected energy and absorbed energy increases with the increasing of the impact pressure. The transmitted energy is almost unaffected by the impact pressure and the average strain rate, it is stable in the range of 15 23J.

The dynamic strength of acid rock has obvious correlation with the absorbed energy. The higher the impact pressure is, the greater the absorption energy is, the higher dynamic compression strength is. The increase of dynamic strength is mainly due to the micro cracks developing not timely, Especially for three-dimensional loading. 
Acknowledgments. This work is supported by the Natural Science Foundation of China (51664014, 51274101) and Science and technology project of Jiangxi Provincial Department of Education (GJJ160474).

\section{References}

1. He M, Xie H, Peng S, et al., Chin J.Rock Mech. Eng., 24, 2803, 2005.

2. Guo L J, Yang Y H, Hua Y H, et al. Experimental study of dynamic characteristics of granite under impact loading. Engineering Blasting, 2014,(01):1-4+53.

3. Li J C, Ma G W, Int. J.Rock Mech.Mining Scie., 46(3), 471, 2009.

4. Li X B, Gong F, Zhao J, et al. Chin J. Rock Mech. Eng., 29, 251, 2010.

5. Gong F, Li X, Liu X, et al. Chin J.Rock Mech. Eng., 29,.2076, 2010.
6. Li X, Zuo Y, Ma D. Chin J. Rock Mech. Eng., 24,.2814, 2005.

7. Zhao F, Wang H, Peng Y, et al. Chin J. Rock Mech. Eng., 131, 1363, 2012.

8. Yin T, Li X, Ye Zh et al. Chin J. Rock Mech. Eng., 32,1197, 2013

9. Tang C, THAM L G, LEE P K K, et al. Int. J.Rock Mech.Mining Scie. , 37, 555, 2000.

10. Zou Y, Li X, Tang C, et al. Chin J.Rock Mech. Eng., 25, 1809, 2006.

11. Xie H, Ju Yang, Li L, Chin J.Rock Mech.Eng., 24, 3003, 2005.

12. Chen X, Zhan Q., J. Mining \& Safety Eng., 27,.179, 2010 .

13. Hong L.Size effect on strength and energy dissipation in fracture of rock under impact loads. $\mathrm{Ph}$. D. Thesis. Changsha: Central South University, 2008. 